УДК 347.1

DOI https://doi.org/10.51989/NUL.2021.4.42

\title{
МОРАЛЬ ТА ПУБЛІЧНИЙ ПОРЯДОК ЯК УМОВА ПАТЕНТОЗДАТНОСТІ БІОТЕХНОЛОГІЧНИХ ВИНАХОДІВ У СФЕРІ МЕДИЦИНИ: ДОСВІД ЄВРОПЕЙСЬКИХ КРАЇн
}

\section{Шишко Ігор Миколайович,}

аспірант кафедри цивільного права № 1

Національного юридичного університету імені Ярослава Мудрого

Статтю присвячено дослідженню проблемних питань застосування такої умови патентоздатності винаходів у сфері біомедичних технологій, як відповідність нормам моралі та публічному порядку.

Наголошуємо, що, зважаючи на стрімкий розвиток біомедичних технологій, які супроводжується їх патентуванням, з одного боку, та необхідністю захистити людину, ї̈ права та гідність від негативного впливу останніх, з іншого боку, дослідження проблемних питань застосування вказаної умови патентоздатності стає вкрай актуальним.

Метою статті було вивчення таких оціночних категорій, як мораль та публічний порядок у контексті патентування біомедичних технологій та визначення критеріїв, які 6 надали можливість установити, який винахід відповідає досліджуваній умові патентоздатності, а який ні, а також установити приблизний перелік біомедичних технологій, які не відповідають досліджуваній умові патентоздатності.

На підставі аналізу міжнародних і регіональних нормативно-правових актів, а також практики правозастосовних органів, зокрема Суду Європейського союзу та Європейського патентного відомства, було встановлено два критерії відповідності винаходів нормам моралі та публічному порядку, а саме: первинний (незавдання шкоди життю та здоров'ю людини) і вторинний (несуперечність людській гідності). Особлива увага була приділена дослідженню вторинного критерію й такої етико-правової категорії, як людська гідність, оскільки відсутність чіткого визначення терміна «людська гідність» та високий ступінь його оціночності значно ускладнюють процес установлення відповідності винаходів досліджуваній умові патентоздатності. Більше того, було встановлено приблизний перелік біомедичних технологій, які не відповідають досліджуваній умові, що значно полегшить процес установлення відповідності винаходів у сфері біомедичних технологій нормам моралі та публічному порядку.

Ключові слова: біомедичні технології, винаходи у сфері біомедичних технологій, патентоздатність винаходів у сфері біомедичних технологій, умови патентоздатності винаходів у сфері біомедичних технологій, мораль, публічний порядок, людська гідність.

Shyshko Ihor. Morality and public order as a condition of patentability of biotechnological inventions in the field of medicine: European experience

The article is devoted to the study of problematic issues of application of such a condition of inventions patentability in the biomedical technologies field as compliance with moral norms and public order.

It has been emphasized that due to the rapid development of biomedical technologies, accompanied by their patenting, on the one hand, and the need to protect people, their rights and dignity from the negative impact of the latter, on the other hand, the study of problematic issues of patentability becomes extremely important.

The aim of the article was to study such evaluation categories as morality and public order in the context of biomedical technologies patenting and to define criteria that would allow to determine which invention meets the studied condition of patentability and which does not, and to establish an approximate list of biomedical technologies, which do not meet the studied patentability condition.

Based on the analysis of international and regional legal acts, as well as the practice of law enforcement agencies, in particular, the European Union Court of Justice and the European Patent Office, two criteria have been established for compliance of inventions with norms of morality and public order, namely, primary (causing no harm to human life and health) and secondary 
(consistency of human dignity). Special attention has been paid to the study of the secondary criterion and such an ethical and legal category as human dignity, as the lack of a human dignity term clear definition and its high degree of evaluation significantly complicate the process of establishing the inventions conformity to the investigated patentability condition. Moreover, an approximate list of biomedical technologies that do not meet the studied condition has been defined, which will greatly facilitate the process of establishing the conformity of inventions in the biomedical technologies field to the norms of morality and public order.

Key words: biomedical technologies, inventions in the field of biomedical technologies, patentability of inventions in the field of biomedical technologies, conditions of patentability of inventions in the field of biomedical technologies, morality, public order, human dignity.

Стрімкий розвиток медичних біотехнологій (далі - МБ), який спостерігається останні десятиліття, відкрив для людей абсолютно нові можливості з лікування та запобігання хворобам людського організму. Такі можливості МБ, з одного боку, піднімають медицину на абсолютно новий (вищий) рівень розвитку, що, безумовно, породжує позитивні наслідки як для кожної окремої людини, так і для всього суспільства. Наприклад, генні технології надають можливість вносити зміни в генетичний апарат клітин людини, що потенційно дозволить лікувати багато захворювань людського організму: гемофілію, муковісцидоз, лейкемію, вірусні захворювання, алергії та імунологічні захворювання, онкологічні, серцево-судинні захворювання та інші [1]. 3 іншого боку, такі можливості МБ породжують нові загрози, пов'язані з порушенням норм моралі та приниженням людської гідності, що, безумовно, можна охарактеризувати як негативні наслідки. Наприклад, вивчення генних технологій пов'язано з проведенням експериментів на ембріонах людини та їх загибеллю внаслідок таких експериментів.

Такий дуалістичний характер наслідків використання МБ вимагає створення правового механізму стримувань, який мінімізує негативні наслідки використання останніх. Особливо гостро необхідність створення такого механізму проявляється в той момент, коли МБ стають об'єктами патентної охорони, оскільки патентування нерозривно пов'язане з комерційним та промисловим використанням вказаних технологій, що підвищує ризики настання та небезпечність негативних наслідків.

Провідні держави, розуміючи необхідність додержання балансу між позитивними і негативними наслідками використання МБ та прагнучи мінімізувати останні, почали вибудовувати системи патентної охорони на основі поєднання норм права з нормами моралі, які, доповнюючи норми права, повинні забезпечити дотримання балансу позитивних та негативних наслідків, забороняючи патентування МБ, негативні наслідки використання яких нівелюють будь-які позитивні. Результатом такого симбіозу стала поява такої умови патентоздатності, як відповідність винаходу нормам моралі та публічному порядку.

Одним із перших нормативно-правових актів, який на міжнародному рівні запровадив указану умову патентоздатності, була Угода про торговельні аспекти права інтелектуальної власності від 15.04.1994 року (далі - ТРІПС), яка в ч. 2 ст. 27 закріпила право держав не допускати патентування винаходів, перешкоджання комерційному використанню яких на їхній території необхідно для захисту громадського порядку (ordre public) або суспільної моралі, зокрема охорони життя або здоров'я людей [2]. У даному випадку ТРІПС не просто ввела додаткову умову патентоздатності, вона надала первинний критерій, за допомогою якого можна встановити відповідність винаходів ч. 2 ст. 27 ТРІПС.

Так, винаходи відповідають нормам моралі та публічному порядку в тому випадку, якщо їх використання не буде завдавати шкоду життю та здоров'ю людини. Аналіз положень ТРІПС свідчить про те, що вона закріпила лише первинний бар'єр захисту людини й суспільства від негативних наслідків патентування МБ, захистивши виключно основоположні права людини на життя та здоров'я.

Водночас буде помилкою вважати, що винаходи, використання яких не завдає шкоди життю та здоров'ю людей, не будуть порушувати норми моралі та публічний 
порядок, оскільки використання винаходу може й не завдавати шкоди життю чи здоров'ю людини, однак таке використання може бути недопустимим з точки зору моралі та/або публічного порядку. Яскравим прикладом $\epsilon$ винаходи, використання (застосування) яких призводить до загибелі ембріонів людини. У даному випадку використання винаходів не завдає шкоду життю чи здоров'ю людини, однак завдає шкоду людській гідності, що, безсумнівно, суперечить моралі та публічному порядку.

Зважаючи на викладене, виникає необхідність у більш детальному з'ясуванні сутності таких оціночних категорій, як мораль та публічний порядок у контексті патентоздатності МБ та встановлення критеріїв, які стануть орієнтирами визначення того, чи відповідає певний винахід у сфері МБ нормам моралі та публічному порядку, чи ні. На нашу думку, для встановлення таких критеріїв першочергово необхідно звернутися до положень міжнародних договорів, які регулюють відносини у сфері МБ, оскільки такі договори розроблялися, з одного боку, з метою врегулювати такі відносини, а з іншого - з метою захистити людину, ії̈ основоположні права та гідність від загроз, які можуть виникати внаслідок їх використання.

Підвалини регулювання біомедичних технологій на міжнародному рівні заклали два міжнародні договори, а саме: Загальна декларація про геном людини та права людини від 11.11.1997р. (далі - Загальна декларація) та Конвенція про захист прав і гідності людини щодо застосування біології та медицини: Конвенція про права людини та біомедицину від 04.04.1997 р. (далі - Конвенція Ов'єдо). Основною метою обох міжнародних договорів $\epsilon$ захист людини, її прав та гідності від негативних наслідків, які можуть виникнути в результаті неконтрольованого використання МБ. Задля досягнення поставленої мети вказаними договорами встановлені обмеження використання МБ, а також наведені приклади МБ, використання яких може порушувати права людини й зачіпати людську гідність, як наслідок - порушувати норми моралі та публічний порядок.

Так, ст. 1 Загальної декларації визначає, що геном людини лежить в основі початкової спільності всіх представників людського роду, а також визнання їх невід'ємної гідності й різноманітності. Як наслідок, ст. 11 Загальної декларації встановлює недопустимість практики, що суперечить людській гідності, такої як клонування в цілях відтворення людини [3]. Із цих положень слідує, що вказаний міжнародний документ встановлює ще один критерій відповідності нормам моралі та публічному порядку - суперечність людській гідності. Таким чином, якщо біотехнологічний винахід буде суперечити людській гідності, він буде суперечити нормам моралі та публічному порядку, оскільки такий винахід буде порушувати одне з основоположних прав людини право на повагу до гідності. Більше того, вказаний документ наводить приклад МБ, використання якої суперечить людській гідності, а отже, й нормам моралі та публічному порядку, - це клонування з метою відтворення людини. Тобто клонування з іншою метою (наприклад, терапевтичною) Загальна декларація визнає таким, що відповідає нормам моралі та публічному порядку. Слід зауважити, що репродуктивне клонування (клонування з метою відтворення людини) - це лише один із прикладів технологій, які суперечать людській гідності, іншими прикладами можуть бути технології, які дозволяють вибирати ембріон за ознакою статі або створювати химер за допомогою трансгенези [4].

Конвенція Ов'єдо встановлює регулювання для МБ, використання яких становить загрозу для прав людини та людської гідності та, як наслідок, суперечить нормам моралі та публічному порядку. Так, ст. 13 цієї Конвенції передбачено, що втручання з метою видозміни геному людини може здійснюватися лише у профілактичних, діагностичних або лікувальних цілях і тільки в тому випадку, якщо воно не має на меті внесення будь-яких видозмін у геном нащадків [5]. Недотримання вказаних правил під час використання генних технологій потенційно може спричинити наслідки, які будуть становити загрозу для людської гідності, а отже, будуть суперечити нормам моралі та публічному порядку.

У свою чергу ст. 14 Конвенції Ов'єдо встановлює вимоги та заборони для 
репродуктивних технологій. Відповідно до вказаної статті, використання медичних репродуктивних технологій з метою селекції статі майбутньої дитини не дозволяється, за винятком випадків, коли необхідно уникнути серйозного спадкового захворювання, пов'язаного зі статтю [5]. Таким чином, технологія, яка буде дозволяти вибирати стать майбутньої дитини, не буде зачіпати людську гідність лише в тому випадку, якщо вона буде використовуватися виключно для лікування генетичних захворювань. Використання вказаних технологій з іншою метою може зачіпати людську гідність і, як наслідок, суперечити нормам моралі та публічному порядку.

Конвенція Ов'єдо також установлює правила та заборони щодо використання ембріонів людини. Відповідно до ст. 18 вказаної конвенції, якщо законодавство дозволяє проводити дослідження на ембріонах in vitro, воно забезпечує належний захист ембріона. Однак вирощування ембріонів людини для дослідних цілей забороняється [5]. У даному випадку конвенція встановила заборону для вирощування ембріонів для дослідних цілей, оскільки така практика становить загрозу для гідності людини, а тому суперечить нормам моралі та публічному порядку.

Варто зауважити, що додатковим протоколом до Конвенції про захист прав і гідності людини щодо застосування досягнень біології та медицини стосовно заборони клонування людських істот від 12.01.1998 року встановлено заборону репродуктивного клонування. Відповідно до ст. 1 вказаного протоколу забороняється будь-яке втручання з метою створення людської істоти, генетично ідентичної іншій людській істоті, живій або померлій [6]. Положення вказаного протоколу ще раз підкреслюють, що репродуктивне клонування $\epsilon$ технологією, яка суперечить людській гідності, а тому суперечить нормам моралі та публічному порядку.

Таким чином, вказані міжнародні документи встановили ще один критерій відповідності МБ нормам моралі та публічному порядку. Так, згадані технології відповідають нормам моралі та публічному порядку в тому випадку, якщо їх використання не суперечить людській гідності. Більше того, міжнародні документи визначили перелік МБ, які в будь-якому разі не відповідають вказаному критерію, а саме: 1) клонування в цілях відтворення людини; 2) втручання в геном людини, здійснене не з профілактичною, діагностичною або лікувальною метою; 3) втручання у геном людини, здійснене з метою видозміни геному нащадків; 4) репродуктивні технології, метою яких $\epsilon$ селекція статі майбутньої дитини, за винятком випадків, коли необхідно уникнути серйозного спадкового захворювання, пов'язаного зі статтю; 5) вирощування ембріонів людини для дослідних цілей.

Важливо зауважити, що вказаний перелік не $\epsilon$ вичерпним, а тому під час встановлення того, чи відповідає конкретна технологія вказаному критерію, необхідно з'ясувати, чи не суперечить така технологія людській гідності. У свою чергу встановлення факту суперечливості певної технології людській гідності вважається за можливе лише після встановлення сутності такої правової категорії, як людська гідність.

Людська гідність як правова категорія згадується в багатьох міжнародних та національних нормативно-правових актах, однак чіткого визначення вказаного терміна не надає жоден із них. Проаналізувавши міжнародні нормативно-правові акти, можна стверджувати, що людська гідність $€$ багатоаспектною та неоднорідною правовою категорією, яка в залежності від мети звернення до неї може мати різні сутності. Серед них можна виділити: 1) загальне чи абстрактне звернення до людської гідності, яке застосовується з метою виділення основних соціальних цінностей і засад функціонування суспільства; 2) нормативне звернення до людської гідності, яке визначає систему ідеальних або бажаних соціальних зав'язків, які лежать в основі взаємовідносин між людьми; 3) позанормативне звернення, яке застосовується для реалізації чи закріплення конкретних прав людини [7].

Таким чином, людська гідність може визначатися як система фундаментальних норм, принципів та цінностей, які визнані суспільством як ідеальна модель соціальних зав'язків між людьми та як форма 
закріплення, реалізації та захисту конкретних прав людини.

3 аналізу міжнародних нормативноправових актів, що регулюють відносини, пов'язані з використанням МБ (Загальна декларація, Конвенція Ов'єдо та інші), можна побачити, що вони апелюють до людської гідності саме як до певного морально-етичного стандарту, тобто до основних соціальних цінностей і засад функціонування суспільства, які визнані суспільством. Таким чином, підставою визнання МБ такими, що суперечать людській гідності, буде суперечність останніх морально-етичному стандарту, який визнаний певним суспільством. Слід зауважити, що вказаний морально-етичний стандарт $\epsilon$ динамічним, оскільки постійно змінюється під дією багатьох факторів: рівня розвитку науки, рівня освіченості людей, культури, релігії, яку сповідують люди, звичаїв та ін. Саме тому згаданий морально-етичний стандарт буде відрізнятися не тільки в різних країнах, але й у різних людей.

Вищевикладене одразу породжує ще одну проблему, яка полягає у встановленні чітких меж згаданого моральноетичного стандарту. На нашу думку, встановлення саме чітких меж $\epsilon$ неможливим і недоречним, оскільки, по-перше, наука розвивається настільки швидко, що передбачити точний перелік технологій, які можуть суперечити людській гідності, або чіткі критерії віднесення технологій до таких, що суперечать людській гідності, неможливо. По-друге, такий перелік або критерії повинні бути санкціоновані суспільством, що майже неможливо, оскільки в суспільстві відсутня єдність у питаннях прийнятності використання тих чи інших біотехнологій. По-третє, одна й та сама біотехнологія в різних ситуаціях може по-різному оцінюватися з точки зору суперечності людській гідності.

Однак вищевикладене не свідчить, що таких меж взагалі не існує. Загальні межі морально-етичного стандарту викладені в міжнародних договорах, які підписані більшістю розвинених країн світу (тобто санкціоновані суспільством), зокрема, такі межі викладені в Загальній декларації, Конвенції Ов'єдо, Директиві Європейського Парламенту та Ради Європейського
Союзу про правову охорону біотехнологічних винаходів від 06.06.1998 р. та інших договорах. Більше того, наявність лише загальних меж дозволяє застосовувати морально-етичний стандарт з урахуванням існуючого рівня розвитку суспільства, існуючих етичних та моральних норм, існуючого рівня розвитку науки та інших мінливих факторів.

Таким чином, суб'єкти правозастосування (орган судової влади, патентне відомство або інший уповноважений орган) повинні застосовувати морально-етичний стандарт, виходячи зі свого внутрішнього переконання, враховуючи мінливі фактори та в обов'язковому порядку з дотриманням загальних меж, які встановлені міжнародними та національними нормативно-правовими актами. Слід зауважити, що примірні переліки біомедичних технологій, які суперечать людській гідності та нормам моралі/публічному порядку, що згадується вище, $є$ тими загальними межами, якими повинні керуватися суб'єкти правозастосування під час установлення того, чи не суперечить певна технологія людській гідності.

Подальший розвиток положень щодо непатентоздатності винаходів у сфері МБ, які суперечать нормам моралі та публічному порядку, був здійснений на регіональному рівні в Директиві Європейського Парламенту та Ради Європейського Союзу про правову охорону біотехнологічних винаходів від 06.06.1998 року (далі - Директива), яка об'єднує міжнародні напрацювання, викладені в трьох попередніх документах. Вказана Директива, як і попередні міжнародні договори, апелює до людської гідності як до певного морально-етичного стандарту. Так, в її преамбулі вказано на необхідність поважати людську гідність, а також на неможливість надання патентної охорони винаходам, які принижують людську гідність.

Повертаючись до питання заборони патентування винаходів, які порушують норми моралі та публічний порядок, Директива його врегулювала у статті шостій, відповідно до якої не можуть бути запатентовані винаходи, чиє комерційне використання суперечить публічному порядку і моралі [8]. У пункті 2 вказаної статті наведено невичерпний перелік методів 
біомедичних технологій, які $\epsilon$ непатентноздатними, основуючись на вимогах п. 1 ст. 6 Директиви. До таких технологій належать:

1) Процеси клонування людей. Варто зауважити, що відповідно до п. 41 преамбули Директиви під клонуванням розуміється будь-який процес, включно 3 методами розщеплення ембріонів, направлений на створення людини, яка буде генетично ідентичною до іншої живої чи мертвої людини [8]. Таким чином, заборона, передбачена в п. 2 ст. 6 Директиви, накладається виключно на репродуктивне клонування, метою якого $\epsilon$ створення людини. Тобто інші види клонування (наприклад, терапевтичне клонування) не віднесено до переліку методів біомедичних технологій, які порушують норми моралі та публічний порядок;

2) Процеси модифікації генетичної ідентичності людини, укладеної в її зародкової лінії;

3) Використання людських ембріонів у комерційних і промислових цілях. Щодо наведеної заборони преамбула Директиви передбачає виключення. Так, відповідно до п. 42 Директиви, п.п. С п. 2 ст. 6 Директиви не застосовується до винаходів терапевтичного або діагностичного призначення, які застосовуються до людського ембріону та корисні для останнього [8]. Тобто винаходи, які використовують людський ембріон з промисловою і комерційною метою, відповідають нормам моралі та публічному порядку за умови, що вони мають терапевтичне або діагностичне призначення.

3 вищевикладеного слідує, що, незважаючи на наявний перелік технологій, які за замовчуванням відносяться до таких, що не відповідають нормам моралі та публічному порядку, її положення сформульовані досить абстрактно, що, з одного боку, дозволяє в процесі правозастосування враховувати мінливі чинники, які в різні часові проміжки та в різних країнах по-різному впливають на відповідність певної технології нормам моралі та публічного порядку: існуючі етичні норми; існуючий рівень розвитку науки; діюче національне, міжнародне законодавство та інше. Однак, з іншого боку, така абстрактність унеможливлює право- застосування без додаткового тлумачення положень Директиви, зокрема з'ясування сутності таких термінів, як «людський ембріон», «генетична ідентичність» та інші.

Показовим у даному випадку $\epsilon$ рішення Суду Європейського Союзу (далі - Суд ЄC) у справі Oliver Brüstle $v$ Greenpeace eV від 18.10.2011 р. Так, завданням суду стало тлумачення положень ст. 6 Директиви, а саме п.п. С. п. 2 ст. 6 Директиви, відповідно до якого не можуть одержати патентну охорону технології, які опосередковують використання ембріонів людини в комерційних та промислових цілях. Перед судом були поставлені три запитання, які вимагали від суду здійснити тлумачення п.п. С п. 2 ст. 6 Директиви.

Відповідаючи на перше запитання, Суду $\in C$ необхідно було з'ясувати, що являє собою людський ембріон у контексті п.п. С п. 2 ст. 6 Директиви. У даному випадку Суд ЄC дійшов висновку, що Директива повинна виключати з-під патентної охорони будь-яку технологію, яка може суперечити людській гідності, з чого слідує, що термін «людський ембріон» повинен розумітися в широкому сенсі. Суд ЄС відніс до цього терміна: (1) запліднену яйцеклітину людини; (2) незапліднену яйцеклітину людини, в ядро якої було перенесено ядро зрілої клітини людини; (3) незапліднену яйцеклітину людини, поділ та наступний розвиток якої був простимульований партеногенезом [9].

Варто зауважити, що Суд $Є C$ у даному рішенні визначив критерій, за допомогою якого можна встановити, чи поширюється термін «людський ембріон» на ту чи іншу клітину. Таким критерієм $€$ здатність клітини почати процес розвитку людини. Тобто якщо клітина здатна почати процес розвитку людини, то вона підпадає під термін «людський ембріон», якщо не здатна така клітина не $\epsilon$ ембріоном, а тому немає підстав для застосовування ст. 6 Директиви. Тобто винахід, формула якого передбачає використання клітини, яка нездатна почати процес розвитку людини, відповідає нормам моралі та публічному порядку.

Таке широке тлумачення терміна «людський ембріон» було негативно оцінено науковою спільнотою, оскільки невиправдано поширювало дію заборон, передбачених ст. 6 Директиви, на широке коло 
клітин, що досить сильно уповільнювало розвиток науки у сфері МБ. Унаслідок цього питання тлумачення терміна «людський ембріон» було повторно розглянуто Судом $\in C$, на підставі чого було прийнято рішення у справі International Stem Cell Corporation v Comptroller General of Patents, Designs and Trade Marks від 18.12.2014 року. Суд ЄС у даному рішенні повторно зауважив, що під час визначення того, чи підпадає певна клітина під термін «людський ембріон», необхідно з'ясувати, чи може така клітина розпочати процес розвитку людини. Якщо сучасний розвиток науки дозволяє встановити, що незапліднена людська яйцеклітина, наступний поділ та розвиток якої був штучно простимульований, не здатна розпочати процес розвитку людини, вона не повинна вважатися людським ембріоном [10]. Тим самим Суд ЄC обмежив дію ст. 6 Директиви, визнавши такими, що відповідають нормам моралі й публічного порядку винаходи, формула яких передбачає використання незаплідненої людської яйцеклітини, наступний поділ та розвиток якої був штучно простимульований. Вказана справа ілюструє вплив такого мінливого чинника, як рівень розвитку науки, на відповідність певного винаходу нормам моралі та публічному порядку.

Другим питанням, на яке Суд мав надати відповідь, було те, чи охоплює поняття «використання людського ембріону з промисловою та комерційною метою» використання людського ембріона з науковою метою?

Відповідаючи на це питання, Суд ЄC виходив з того, що видача патенту на винахід за замовчуванням передбачає його використання 3 промисловою та комерційною метою, а тому якщо предметом патентної охорони $\epsilon$ використання людських ембріонів з науковою метою, то його не можна відмежувати від використання ембріону людини з промисловою та комерційною метою [9]. Саме тому винаходи, які передбачають використання ембріонів людини з науковою метою, підпадають під виключення з-під патентної охорони, передбаченої ст. 6 Директиви.

Третім питанням було: чи $є$ непатентоздатним винахід, який безпосередньо не передбачає використання людських емб- ріонів або їх знищення, однак передбачає використання продукту, для виробництва якого необхідно знищити людський ембріон? У даному випадку Суд ЄC, посилаючись на недоторканість людської гідності, дійшов висновку, що винахід повинен визнаватися непатентоздатним навіть у тому випадку, якщо його формула не передбачає використання або знищення ембріонів людини, однак реалізація винаходу передбачає таке використання або знищення [9]. Тобто навіть якщо використання або знищення ембріонів людини відбулося задовго до реалізації винаходу, однак формула винаходу передбачає використання продукту, створення якого передбачає використання або знищення ембріонів людини, то такий винахід буде суперечити нормам моралі та публічному порядку.

Проаналізувавши вказане рішення та майбутній вплив останнього на правозастосовну практику, можна зробити такі висновки. По-перше, Суд ЄС виходить із того, що надання патентної охорони повинно здійснюватися 3 урахуванням поваги та недоторканості людської гідності як однієї з основоположних цінностей суспільства. Як наслідок, Суд ЄС здійснив максимально широке тлумачення п.п. С. п. 2 ст. 6 Директиви, виключивши будь-яку можливість патентування технології, яка може завдати шкоду людській гідності. По-друге, Суд ЄС установив, що норми моралі та публічний порядок $є$ дуже мінливими категоріями, оскільки за існування різних мінливих факторів одна й та ж технологія може відповідати або не відповідати нормам моралі та публічному порядку. Тому під час визначення того, чи відповідає певна технологія нормам моралі та публічному порядку, необхідно враховувати мінливі фактори у вигляді існуючих етичних норм; існуючого рівня розвитку науки; діючого національного, міжнародного законодавства та ін. По-третє, рішення по справі стало прецедентним не тільки для самого Суду $\in C$ і національних судів країн-членів $\in C$, воно стало широко використовуватися як додатковий засіб тлумачення положень щодо непатентоздатності винаходів, які суперечать нормам моралі та публічному порядку, викладених у різних 
нормативно-правових актах (міжнародних, регіональних, національних) судовими органами та патентними відомствами, зокрема Європейським патентним відомством.

Вищевикладене свідчить про те, що розробники Директиви не ставили за мету визначити точну дефініцію таких оціночних категорій, як мораль та публічний порядок, або дати вичерпний перелік технологій, які їх порушують. Більше того, преамбула Директиви підкреслює невичерпність переліку технологій, які можуть суперечити людській гідності та, як наслідок, порушувати норми моралі та публічний порядок. Із цього приводу Суд ЄC у рішенні по справі Kingdom of the Netherlands $v$ European Parliament and Council of the European Union від 09.10.2001 р. вказує, що перелік непатентоздатних технологій, які перелічені в ст. 6 Директиви, не $€$ вичерпним, оскільки будь-які технології, використання яких принижує людську гідність, повинні бути виключені з-під патентної охорони [11]. Тобто Директива, як і більшість міжнародних, регіональних та національних нормативно-правових актів у сфері охорони прав інтелектуальної власності, встановлює лише орієнтири, якими повинні керуватися патентні відомства (регіональні та національні), а також інші уповноважені суб'єкти під час віднесення тієї чи іншої технології до такої, що не відповідає нормам моралі та публічному порядку.

Слід зауважити, що саме патентні відомства $€$ первинними суб'єктами, які приймають рішення щодо патентоздатності винаходів, зокрема щодо визнання останніх такими, що не відповідають нормам моралі та публічному порядку. А тому для з'ясуванні сутності таких оціночних категорій, як норми моралі та публічний порядок в контексті патентоздатності МБ та встановлення критеріїв визначення відповідності певного винаходу у сфері МБ нормам моралі та публічному порядку, необхідно звернутися до правозастосовної практики вказаних суб'єктів.

Одним із найбільш авторитетних патентних відомств світу, беззаперечно, $€$ Європейська патентна організація (далі - ЄПО), яка була заснована Конвенцією про видачу європейських патентів від 05.10.1973 року (далі - Європейська патентна конвенція). Відповідно, Європейська патентна конвенція $\epsilon$ основним документом, який регулює діяльність ЄПО з проведення експертизи та видачі патентів на винаходи в цілому та винаходи у сфері МБ зокрема. У питаннях проведення експертизи винаходів у сфері МБ ЄПО керується не тільки Європейською патентною конвенцією, а й міжнародними договорами та рішеннями судів, незважаючи на те, що обов'язкова дія вказаних документів не поширюється на ЄПО. Із цього приводу Апеляційна палата $Є П О$ у своєму рішенні № G 0002/06 від 25.11.2008 року вказує, що положення міжнародних договорів, зокрема Угоди ТРІПС, а також рішення судів не $\epsilon$ обов'язковими для $€ П О$, однак вони повинні братися до уваги. Щодо Директиви, то остання повинна використовуватися як додатковий засіб тлумачення, оскільки положення Європейської патентної конвенції щодо непатентоздатності біотехнологічних винаходів, які суперечать нормам моралі та публічному порядку, були взяті саме з Директиви [12].

Так, відповідно до ст. 53 Європейської патентної конвенції не можуть бути запатентовані винаходи, чиє комерційне використання суперечить публічному порядку і моралі [13], зокрема: (1) Процеси клонування людей. Відповідно до методичних рекомендацій проведення експертизи заявок Європейським патентним відомством від 1 червня 1978 року (далі - Методичні рекомендації) процес клонування людини - це будь-який процес, включно з методами розщеплення ембріонів, направлений на створення людини, яка буде генетично ідентичною до іншої живої чи мертвої людини [14]. Тобто як і Директива, Методичні рекомендації поширюють заборону патентування лише на репродуктивне клонування, залишаючи поза забороною інші види клонування (наприклад, клонування з терапевтичною метою) як такі, що можуть не порушувати норми моралі та публічний порядок. (2) Процеси модифікації генетичної ідентичності людини, укладеної в її зародковій лінії. (3) Використання людських ембріонів у комерційних і промислових цілях. Відповідно до Методичних рекомендацій, використання 
людських ембріонів у комерційних і промислових цілях поширюється також на винаходи, формула яких не передбачає використання людських ембріонів або їх знищення, однак передбачає використання продукту, для виробництва якого необхідно знищити людський ембріон. Саме тому, визначаючи відповідність певного винаходу нормам моралі та публічному порядку, необхідно провести аналіз не тільки формули винаходу, а й опису винаходу та методів реалізації (застосування) винаходу. При цьому відповідно до рішення апеляційної палати ЄПО № Т 2221/10 від 04.02.2014 року період часу, в якому відбувається таке знищення (наприклад, задовго до процесів, які передбачені в формулі винаходу), не відіграє особливої ролі [14].

Аналіз положень Європейської патентної конвенції та практики апеляційної палати ЄПО свідчить, що остання під час установлення відповідності винаходів нормам моралі та публічному порядку керується Директивою та практикою Суду $\in C$, що свідчить про гармонізацію підходів щодо непатентоздатності винаходів, які суперечать нормам моралі та публічному порядку в рамках Європейського Союзу та країн-членів Європейської патентної конвенції.

Основуючись на вищевикладеному, можна стверджувати, що така умова патентоздатності, як відповідність нормам моралі та публічному порядку, $є$ складним етико-правовим явищем, застосування якого вимагає від відповідних суб'єктів апелювати під час правозастосування не тільки до норм права, викладених у положеннях законодавства, а й до такого соціального регулятора, як норми моралі. Більше того, вказана умова має високий рівень оціночності, що ще більше ускладнює ії̈ застосування на практиці. Незважаючи на це, чинні міжнародні договори та наявна правозастосовна практика значною мірою допомагають суб'єктам правозастосування встановлювати відповідність винаходів нормам моралі та публічному порядку.

Ретельний аналіз міжнародних договорів та правозастосовної практики надав можливість сформувати орієнтири, якими можуть керуватися суб'єкти правозастосування, встановлюючи, чи відповідає певний винахід такій умові патентоздатності, як відповідність нормам моралі та публічному порядку. Такими орієнтирами $є$ два критерії: 1) незавдання шкоди життю та здоров'ю людини; 2) несуперечність людській гідності.

Щодо першого критерію, то винаходи будуть відповідати нормам моралі та публічному порядку в тому випадку, якщо їх використання не завдає шкоду життю та здоров'ю людини. Прикладом винаходу, який не буде відповідати наведеному критерію, $\epsilon$ препарат для евтаназії, оскільки останній направлений на позбавлення життя людини. Щодо другого критерію, то винаходи будуть відповідати нормам моралі та публічному порядку в тому випадку, якщо їх використання не суперечить людській гідності як морально-етичному стандарту, визнаному суспільством. Більше того, щодо другого критерію можна встановити перелік МБ, які повинні бути виключені з-під патентної охорони внаслідок того, що використання останніх суперечить людській гідності, а отже, порушує норми моралі та публічний порядок. До таких МБ належать: 1) репродуктивне клонування людини; 2) втручання в геном людини, здійснене не з профілактичною, діагностичною або лікувальною метою; 3) технології, які опосередковують внесення змін у генетичну ідентичність людини, котрі можуть передаватися нащадкам; 4) технології, які передбачають використання людських ембріонів з промисловою i/або комерційною метою; 5) репродуктивні технології, метою яких $\epsilon$ селекція статі майбутньої дитини, за винятком випадків, коли необхідно уникнути спадкового захворювання, пов'язаного зі статтю.

Варто зауважити, що вказаний перелік не $\epsilon$ вичерпним, він виступає лише як орієнтир, який уповноважені суб'єкти правозастосування повинні використовувати під час установлення того, чи відповідає конкретна технологія такій умові патентоздатності, як відповідність нормам моралі та публічному порядку. 


\section{ЛITEPATУPA:}

1. Этические принципы геномики. Бюллетень медицинских интернет-конференций / С. Ворфоломеев и др. 2017. Том 7. № 6. URL: https://cyberleninka.ru/article/n/eticheskieprintsipy-genomiki/viewer

2. Угода про торговельні аспекти прав інтелектуальної власності від 15.04.1994 року. URL: https://zakon.rada.gov.ua/laws/show/981_018\#Text

3. Загальна декларація про геном людини та права людини від 11.11.1997 року. URL: https://zakon.rada.gov.ua/laws/show/995_575\#Text

4. Звіт департаменту етики науки та техніки ЮНЕСКО, опублікований в липні 1999 року. URL: http://www.unesco-chair-bioethics.org/wp-content/uploads/2015/05/119390eo.pdf

5. Конвенція про захист прав і гідності людини щодо застосування біології та медицини: Конвенція про права людини та біомедицину від 04.04.1997 року. URL: https:// zakon.rada.gov.ua/laws/show/994_334\#Text

6. Додатковий протокол до Конвенції про захист прав і гідності людини щодо застосування досягнень біології та медицини, стосовно заборони клонування людських істот від 12.01.1998 року. URL: https://zakon.rada.gov.ua/laws/show/994_526\#Text

7. Велика українська юридична енциклопедія / В.О. Абашнік та ін. ; редкол. 2-го т.: С.І. Максимов (голова) та ін. Харків : Право, 2017. Т. 2: Філософія права. 1127 с.

8. Директива Європейського Парламенту та Ради Європейського Союзу про правову охорону біотехнологічних винаходів від 06.06.1998 року. URL: https://eur-lex.europa.eu/legalcontent/EN/TXT/?uri=celex\%3A31998L0044

9. Рішення великої палати Суду Європейського Союзу у справі Oliver Brüstle v Greenpeace eV від 18.10.2011 року. URL: http://curia.europa.eu/juris/liste.jsf?language=en\&num=C-34/10

10. Рішення великої палати Суду Європейського Союзу у справі International Stem Cell Corporation v Comptroller General of Patents, Designs and Trade Marks від 18.12.2014 року. URL: http://curia.europa.eu/juris/liste.jsf?num=C-364/13

11. Рішення Суд Європейського Союзу у справі Kingdom of the Netherlands $v$ European Parliament and Council of the European Union від 09.10.2001 року. URL: http://curia.europa.eu/ juris/liste.jsf?language $=$ en\&num $=\mathrm{C}-377 / 98$

12. Рішення апеляційна палата Європейської патентної організації № G 0002/06 від 25.11.2008 року. URL: https://www.epo.org/law-practice/case-law-appeals/recent/ g060002ex1.html

13. Конвенцією про видачу європейських патентів від 05.10.1973 року. URL: https:// www.epo.org/law-practice/legal-texts/epc.html

14. Методичні рекомендації проведення експертизи заявок Європейським патентним відомством від 1 червня 1978 року. URL: http://documents.epo.org/projects/babylon/eponet. nsf/0/8654640290C2DBE7C12584A4004D2D9A/\$File/epo_guidelines_for_examination_2019_ hyperlinked_en.pdf

15. Рішення апеляційної палати Європейської патентної організації № T 2221/10 від 04.02.2014 року. URL: https://www.epo.org/law-practice/case-law-appeals/recent/ t102221eu1.html 